\title{
Feeding behavior and morphological adaptations in two sympatric sea urchin species in central Chile
}

\author{
S. Contreras \& J. C. Castilla \\ Estación Costera de Investigaciones Marinas, Facultad de Ciencias Biológicas, Pontificia Universidad Católica de Chile, \\ Casilla 114-D, Santiago, Chile
}

\begin{abstract}
Loxechinus albus and Tetrapygus niger are 2 sympatric sea urchin species present in the rocky intertidal and subtidal zones of central Chile. In this study we test the hypothesis that the 2 species employ different feeding mechanisms, and that this has resulted in distinct ecological roles for the 2 species. We also analyze structures associated with feeding. Results from field studies indicate that $T$ niger principally consumes benthic algae (i.e. Gelidium spp.) and in doing so clears significantly more primary space than does $L$. albus. Laboratory experiments confirmed this observation, and demonstrated that $T$. niger consumes significantly more benthic algae (i.e. Gelidium spp.) attached to rock than floating algal pieces (i.e. Lessonia nigrescens). Small $L$. albus $(<3 \mathrm{~cm}$ diameter) consume significantly more benthic than floating algae pieces; the reverse is true for large $(>3 \mathrm{~cm}$ diameter) individuals. While oral podia in both species are modified terminally to form suckers, only $L$. albus possesses such modifications on aboral podia. Additionally, in $T$. niger the pyramids of Aristotle's lantern are roughly twice as long as those in $L$. albus. We discuss the possible ecological roles of each species with reference to the structure of intertidal communities.
\end{abstract}

\section{INTRODUCTION}

Feeding behavior and ecology of sea urchins are well known (see reviews by Reese 1966, Lawrence 1975). Two basic mechanisms of obtaining food have been described: (1) removal of algae and sessile invertebrates from hard substrate by means of the powerful teeth of the Aristotle's lantern, and (2) capture of drift algae by the ambulacral podia and spines and the subsequent transport of this material to the mouth. These 2 mechanisms are not mutually exclusive, even within a single species. In Strongylocentrotus purpuratus, for example, the factors which influence the selection of either mode include: availability of drift algae (Leighton 1971); habitat used by different sea urchin size classes (Dayton 1975); the daily cycle (Tegner \& Levin 1983); and wave exposure (Dayton 1985). Since the specific feeding mechanism(s) employed may influence the effect that a sea urchin has on its community, it is important to incorporate analyses of feeding mechanism into evaluations of the roles of sea urchins.

In addition to variation in feeding mechanism, sea urchins may also vary in the size of the feeding apparatus. For example, Ebert (1980) and Black et al. (1982) have demonstrated that the size of the Aristotle's lantern in Diadema setosum, $S$. purpuratus, and Echinometra mathei is related to the availability of food in the environment and that individual sea urchins allocate more resources to the jaw apparatus when food is scarce (Ebert 1980). Both papers reported that sea urchins obtained from sites where their density is very high (see also Black et al. 1984) have larger lanterns than individuals from sites where food is more abundant.

Based on preliminary observations, we hypothesized that the 2 sympatric intertidal and subtidal sea urchins of central Chile, Loxechinus albus and Tetrapygus niger, employ different feeding mechanisms. This paper describes the field and laboratory conditions in which we assayed the hypothesis that $T$. niger grazes and $L$. albus captures drifting algae. Furthermore, we analyze the main morphological structures involved in food gathering for both species, Aristotle's lantern and podia, with the aim of exploring possible morphologically adaptive structures. 


\section{MATERIALS AND METHODS}

Field experiments. Experiments in exposed intertidal rocky pools along the central Chilean coast at El Quisco $\left(33^{\circ} 23^{\prime} S_{i} 71^{\circ} 42^{\prime} \mathrm{W}\right.$ ) were carried out between October 1982 and January 1983.

Sea urchins and boulders with algae added to pools. Six pools of similar size and biotic composition were selected. Pools were 60 to $70 \mathrm{~cm}$ long, 45 to $50 \mathrm{~cm}$ wide and 50 to $60 \mathrm{~cm}$ deep, and contained both sea urchin species, other herbivores, and crustose calcareous algae. All sea urchins and other herbivore species were removed from the pools. Subsequently, 2 of these pools had Loxechinus albus added, 2 had Tetrapygus niger added, and 2 were left without herbivores. Each sea urchin-addition pool received 10 sea urchins from 3 to 4 $\mathrm{cm}$ and 5 boulders 20 to $25 \mathrm{~cm}$ long. Gelidium spp. constituted 80 to $90 \%$ of the algal cover on the boulders. Daily measurements of algal cover were made on 3 diurnal low-tides. Algal cover on each boulder was recorded by tracing the outline on transparent acetate sheets. Areas were subsequently measured with a Ushikata Digi Plan 220-L planimeter. The amount of algae consumed was expressed as the area of consumed algae minus a correction factor obtained from the control pools.

Addition of sea urchins to pools and with algae. Six pools of similar size ( 30 to $40 \mathrm{~cm}$ long, 40 to $50 \mathrm{~cm}$ wide and 20 to $30 \mathrm{~cm}$ deep) were selected, containing mainly the following macroalgae: Gelidium chilense, Ulva spp. and Codium dimorphum. The algal species were identifed in each pool and the algal cover of walls and bottom of the pool was measured with a $25 \times 25 \mathrm{~cm}$ quadrat using 50 point intersects. Subsequently, in 4 of these pools, 10 sea urchins of 4 to $5 \mathrm{~cm}$ were added: Loxechinus albus in 2 pools and Tetrapygus niger in 2 other pools. Two pools were left without sea urchins and served as controls. Pools were monitored at $15 \mathrm{~d}$ and subsequently every $30 \mathrm{~d}$ for $3 \mathrm{mo}$. Algal cover was estimated and sea urchin densities adjusted to original levels.

Laboratory experiments. The 2 sea urchin species were collected by hand from the intertidal zone at Las Cruces $\left(33^{\circ} 30^{\prime} \mathrm{S} ; 71^{\circ} 38^{\prime} \mathrm{W}\right.$ ) between July and August 1981 , and at Pelancura $\left(33^{\circ} 32^{\prime} \mathrm{S} ; 71^{\circ} 38^{\prime} \mathrm{W}\right)$ in January and August 1985. Experiments were carried out in 2 types of aquaria.

(1) A recirculating seawater aquarium (RSWA) was used at the Catholic University in Santiago. Water temperature fluctuated between 11 and $12{ }^{\circ} \mathrm{C}$; salinity ranged from 35 to $37 \%$ and the photoperiod was $12 \mathrm{~h}$ light and $12 \mathrm{~h}$ darkness (Castilla \& Cancino 1976).

(2) Open seawater aquaria were located at the Estación Costera de Investigaciones Marinas (ECIM) at Las Cruces. Water temperature fluctuated from 14 to $20^{\circ} \mathrm{C}$ and salinity between 34 and $35 \%$ with a natural photoperiod.

Three algal choice experiments with algae available as floating pieces, loose benthic pieces or attached to rocks were performed. In Santiago (RSWA), groups of 10 sea urchins with a test diameter of 3 to $3.5 \mathrm{~cm}$ were used in $20 \mathrm{l}$ plastic tanks. At Las Cruces (ECIM), the following series were run: (a) groups of 10 sea urchins of 1 to $2 \mathrm{~cm}$ in 21 plastic tanks; (b) groups of 10 sea urchins of 3 to $3.5 \mathrm{~cm}$ in $20 \mathrm{ltanks;}$ (c) groups of 5 sea urchins of 3.5 to $4.5 \mathrm{~cm}$ in $20 \mathrm{l}$ tanks. Food was offered to these groups as follows:

Floating pieces of algae. Twenty $g$ wet weight of Lessonia nigrescens was added to each $20 \mathrm{l}$ tank and 2 $g$ (wet weight) of $L$. nigrescens was placed into each 21 tank in uniformly cut pieces $\left(6 \mathrm{~cm}^{2}\right.$ and $3 \mathrm{~cm}^{2}$, respectively). In the RSWA, algal pieces were kept afloat through a continuous flow of seawater $\left(10 \mathrm{l} \mathrm{min}^{-1}\right)$ generated by an Eheim pump, Model 1017. At ECIM the flow was $41 \mathrm{~min}^{-1}$ in $20 \mathrm{l}$ tanks and $0.51 \mathrm{~min}^{-1}$ in 21 tanks, obtained from the general seawater supply system. A plastic net cover prevented sea urchins and algae pieces from overflowing the tanks. Six simultaneous replicates were run for each sea urchin species, with each size and each algal species. In RSWA experiments, algal biomass consumed was measured every $12 \mathrm{~h}$. At ECIM algal biomass in experimental (with sea urchins) and control (without sea urchins) tanks was measured every $48 \mathrm{~h}$. Non-consumed algae and algae from control tanks were weighed and the biomass of every tank was completely renewed. The amount of algae consumed was expressed as: dry wet of alga consumed minus the correction factor obtained from loss or gain in control tanks. The dry weight of each algal species used as food was obtained through a calibration curve of wet versus dry weight. (For $L$. nigrescens: $\mathrm{W}=0.018+0.155 \mathrm{~W}$, where $\mathrm{W}=$ dry weight and $\mathrm{w}=$ wet weight).

Loose benthic algal pieces on the bottom of tanks. At ECIM, $20 \mathrm{~g}$ wet weight of Lessonia nigrescens were put in $20 \mathrm{ltanks}$ and $2 \mathrm{~g}$ in $2 \mathrm{l}$ tanks, and in RSWA $20 \mathrm{~g}$ of the same algae were put in $20 \mathrm{l}$ tanks. Water flows were kept at $200 \mathrm{ml} \mathrm{min}^{-1}$ in $20 \mathrm{l}$ tanks, and $0.5 \mathrm{ml}$ $\mathrm{min}^{-1}$ in $2 \mathrm{l}$ tanks. These flows were obtained from the general water system. At RSWA, the experiment was monitored every $12 \mathrm{~h}$ by measuring the biomass of algae consumed. AT ECIM, the experiment was monitored every $48 \mathrm{~h}$.

Algae attached to rocks. This experiment was done at ECIM. Rounded cobbles with longest diameter 5 to $15 \mathrm{~cm}$ and abundant cover of Ulva spp. or Gelidium spp. were added to $20 \mathrm{I}$ and $2 \mathrm{l}$ tanks. In these tanks some algae were removed from the cobbles with spatula and steel brush to produce a varying amount of algal cover. The following algal areas and sea urchin 
sizes were used: (1) $36 \mathrm{~cm}^{2}$ of Ulva spp. or Gelidium spp. and sea urchins between 3 and $3.5 \mathrm{~cm}$; (2) from 16 to $36 \mathrm{~cm}^{2}$ Gelidium spp. and sea urchins between 3.5 and $4.5 \mathrm{~cm}$ and between 5 and $6 \mathrm{~cm}$; and (3) 6 to $10 \mathrm{~cm}^{2}$ Ulva spp. and sea urchins varying from 1 to $2 \mathrm{~cm}$. Six simultaneous replicates were made for each sea urchin species by size and for each algal surface without sea urchins (controls). Changes in algal cover were measured every $48 \mathrm{~h}$. A transparent acetate sheet was used to trace the outline of the algal patch. Areas were then measured with a planimeter. The amount of algae consumed was expressed as the difference between the initial and final algal cover (surface), minus the correction factor obtained from the controls. ANOVA with replication and Mann-Whitney test and $G$ test (Sokal \& Rohlf 1969) were used for inter and intraspecific comparisons in food consumption per sea urchin.

Morphological adaptations. Three morphological structures associated with feeding were studied in each sea urchin species. (1) The number of oral and aboral pores of each ambulacral plate were counted and the external morphology of tube feet was observed under the microscope in 30 individuals, ranging in size from 2.5 to $4.5 \mathrm{~cm}$ in diameter, for each species. (2) The length of each of the 5 pyramids of Aristotle's lantern, from the hard oral end to aboral end, or epiphysis, was measured with a caliper in 80 individuals of Tetrapygus niger ranging from 1 to $7.5 \mathrm{~cm}$ diameter and in 90 individuals of Loxechinus albus ranging from 1 to 10.5 cm diameter. (3) In the same individuals the length of the teeth between the hard oral end (extreme edge) and the inferior (oral) end of the pyramid were measured. In all individuals of both species we plotted the largest pyramid and largest tooth against the sea urchin diameter. An analysis of covariance $\log _{e}$ transformed data was used to test for interspecific differences (Snedecor \& Cochran 1967, Ebert 1980).

\section{RESULTS}

\section{Short-term field experiments}

Fig. 1 shows the decrease in algal cover due to grazing by Tetrapygus niger and Loxechinus albus during $72 \mathrm{~h}$, on boulders added to tidal pools. Gelidium spp. was the most abundant algae on the boulders. In pools without sea urchins, no changes in algal cover were observed. In the presence of $T$. niger and $L$. albus, a reduction in cover was observed. $T$. niger grazed significantly more than L. albus $\left(\mathrm{F}_{1,53}=79.92 ; \mathrm{p}<0.01\right)$.

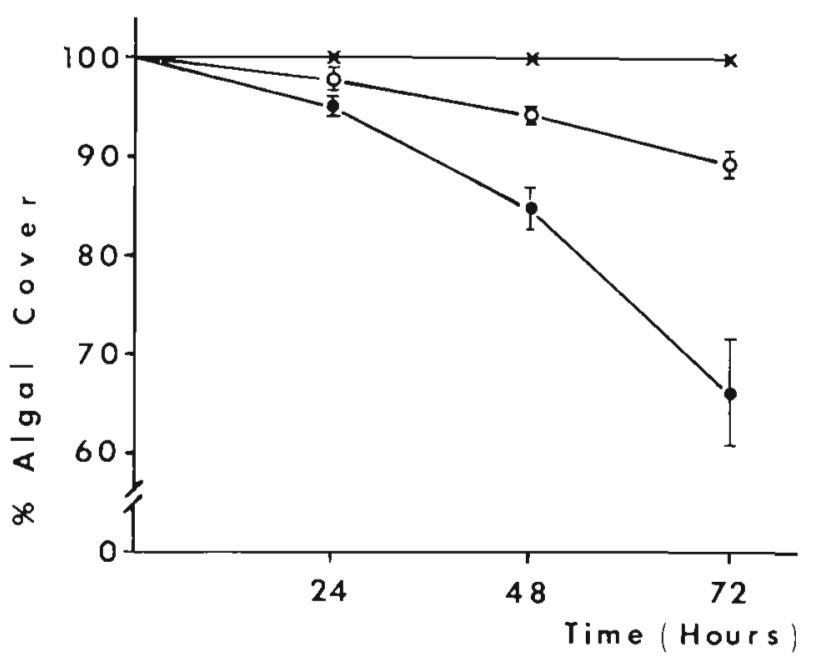

Fig. 1. Tetrapygus niger (•) and Loxechinus albus (0). Decrease in boulder algal cover due to the grazing of sea urchins in tidal pools at El Quisco (October 1982). (x) Boulders without sea urchins. Data are means \pm standard deviation

\section{Long-term field experiments}

Fig. 2 shows the decrease in algal covers due to grazing of Tetrapygus niger and Loxechinus albus on intertidal pool walls during $165 \mathrm{~d}$. In control pools, (without sea urchins) algal cover increased from 83.69 to $98.08 \%$. This change was due to recruitment by various species of macroalgae, primarily Ulva spp., Iridaea laminariodes, Centroceras spp., Ceramium spp. and Lessonia nigrescens. Algal cover in pools with $T$. niger was significantly less than in those with $L$. albus in control pools $\left(G_{[4]}=13.26 ; p<0.01\right)$ from November

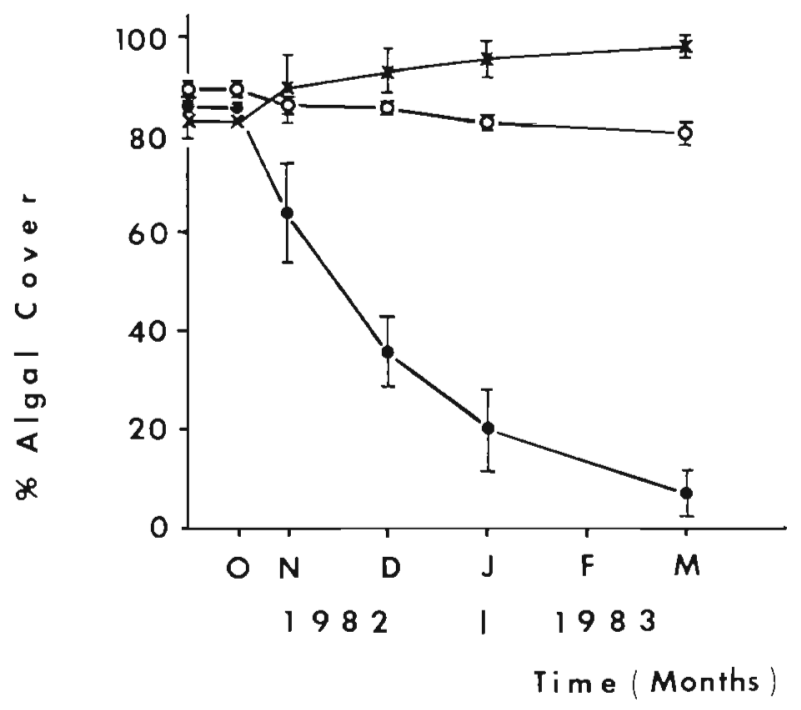

Fig. 2. Tetrapygus niger $(\bullet)$ and Loxechinus albus ( $(0)$. Decrease in intertidal pools algal cover due to grazing of sea urchins at El Quisco (October 1982 to March 1983). (x) Pools without sea urchins. Data are means \pm standard deviation 
to the end of March 1983. There are similar significant differences between the algal cover of control pools (without sea urchins) and pools with $L$. albus between December and March $1983\left(\mathrm{G}_{[1]}=12.84 ; \mathrm{p}<0.01\right)$. It is interesting to note that $T$. niger and $L$. albus begin to graze from the border or edge of the algal patches on either the boulders or walls. The grazing of $T$. niger is more intensive than that $L$. albus and produces big halos around each sea urchin.

\section{Laboratory experiments}

Fig. 3 shows amounts of algae consumed by sea urchins under 3 different experimental regimes. (a) The amount of floating Lessonia nigrescens consumed by small Loxechinus albus (less than $2 \mathrm{~cm}$ in diameter) is not significantly different than that consumed by Tetrapygus niger of similar sizes $\left(\mathrm{U}_{6,6}=18.5 ; \mathrm{p}<0.05\right)$ (Fig. $3 a)$. $L$. albus and $T$. niger over $3 \mathrm{~cm}$ consume significantly more floating algae than do individuals of the same species under $3 \mathrm{~cm}\left(U_{6,6}=35_{i} p<0.01\right)$. There are significant differences between the amounts of floating algae consumed by $L$. albus and $T$. niger over $3 \mathrm{~cm}$ $\left(\mathrm{U}_{6,6}=36 ; p<0.01\right)$. (b) $T$. niger (of all size classes) consumes a significantly greater amount of loose benthic algae than do $L$. albus of similar sizes $\left(\mathrm{U}_{6,6}=36 ; \mathrm{p}<0.01\right)$ (Fig. 3b). (c) Small T. niger and small $L$. albus (both less than $3 \mathrm{~cm}$ ) consume similar amounts of attached algae $\left(U_{6,6}=20 ; p<0.05\right)$. However, larger $T$. niger (over $3 \mathrm{~cm}$ ) consume significantly more attached algae than do L. albus of similar sizes $\left(\mathrm{U}_{6,6}=36 ; \mathrm{p}<0.01\right)$ (Fig. 3c)

Loxechinus albus consumes significantly more floating than loose benthic algae both during the day and the night $\left(\mathrm{U}_{6,6}=36 ; \mathrm{p}<0.01\right)$. Tetrapygus niger consumes significantly more algae during the night, regardless of whether algae were floating or loose benthic $\left(\mathrm{U}_{6,6}=29 ; \mathrm{p}<0.05 ; \mathrm{U}_{6,6}=36 ; \mathrm{p}<0.01\right.$; Table 1). During the night, $T$. niger consumes significantly more loose benthic than floating algae $\left(\mathrm{U}_{6,6}=32\right.$; $p<0.05)$. However, the quantity of floating algae consumed by $T$. niger during the day is not significantly different from the amount of loose benthic algae consumed during the same period $\left(U_{6.6}=20 ; p>0.05\right)$.

\section{Morphological aspects}

Oral and aboral podia and jaw morphology of similar sized Loxechinus albus and Tetrapygus niger $13.8 \mathrm{~cm}$ diameter) are illustrated in Fig. 4. Although the terminal end of the oral podia of both species widen to form a characteristic $P_{3}, P_{4}$ sucking disc (Smith 1978) (Fig. 4a), the terminal ends of their aboral podia differ (Fig. $4 \mathrm{~b}$ ).
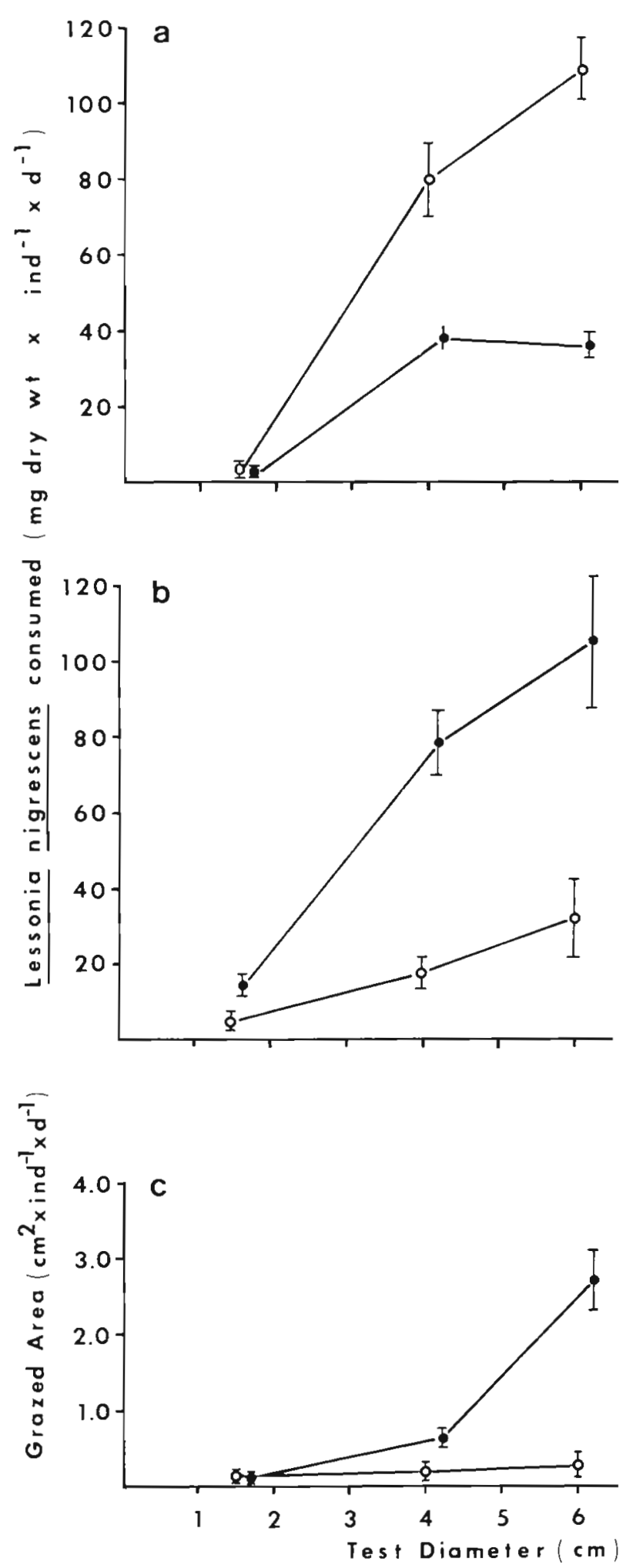

Fig. 3. Loxechinus albus $(\mathcal{O})$ and Tetrapygus niger $(\bullet)$. Algae consumed by 3 size groups of sea urchins in different laboratory regimes: (a) floating Lessonia nigrescens; (b) loose $L$. nigrescens pieces on the bottom of the tanki (c) algae, mostly Gelidium spp, attached to rocks. Experiments carried out at ECIM during Aug 1985. Data are means \pm standard deviation 
Table 1. Loxechinus albus and Tetrapygus niger. Average consumption of Lessonia nigrescens (dry weight) by sea urchins, (3 to $3.5 \mathrm{~cm}$ in diameter), in the floating system and in loose benthic system. Data are means \pm standard deviation. Mann-Whitney U-test, $\alpha=0.05$

\begin{tabular}{|lcccccc|} 
& \multicolumn{2}{c}{ Floating system } & Test & \multicolumn{2}{c|}{ Loose benthic system } & Test \\
& Night $(\overline{\mathrm{X}} \pm \mathrm{SD})$ & Day $(\overline{\mathrm{X}} \pm \mathrm{SD})$ & $\left(\mathrm{U}_{6,6}\right)$ & Night $(\overline{\mathrm{X}} \pm \mathrm{SD})$ Day $(\overline{\mathrm{X}} \pm \mathrm{SD})$ & $\left(\mathrm{U}_{6,6}\right)$ \\
\hline L. albus & $56.30 \pm 8.56$ & $50.28 \pm 8.48$ & $25 \mathrm{~ns}$ & $24.22 \pm 8.23$ & $21.53 \pm 11.42$ & $26 \mathrm{~ns}$ \\
$\begin{array}{l}\text { T. niger } \\
\mathrm{U}_{6.6}\end{array}$ & $31.60 \pm 6.51$ & $21.42 \pm 7.93$ & 29 & $45.10 \pm 8.79$ & $22.82 \pm 4.46$ & 36 \\
\end{tabular}

Fig. 4. Loxechinus albus (left) and Tetrapygus niger (right): morphological aspects. (a) Oral podia; (b) aboral podia; (c) jaw elements of Aristotle's lantern. Podia and jaw came from individuals of similar test diameter $(3.8 \mathrm{~cm})$ $\mathbf{a}$

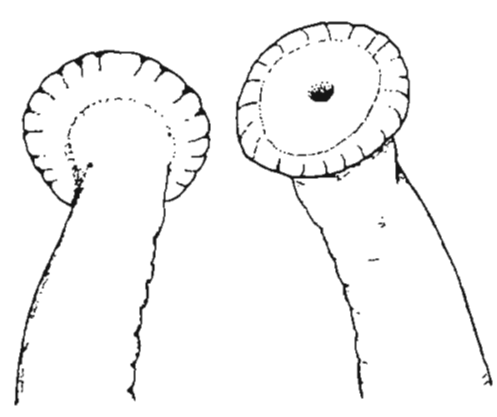

b

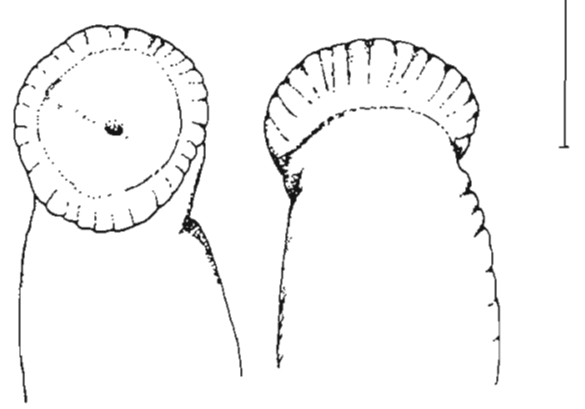

c

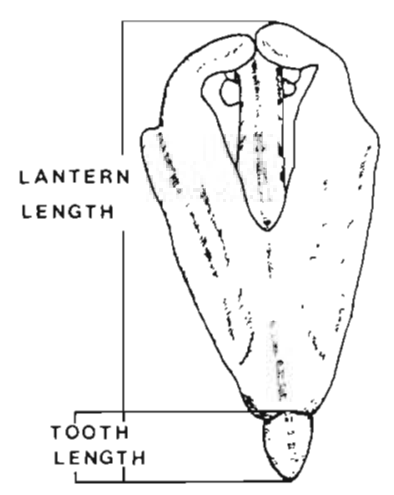

Tetrapygus niger
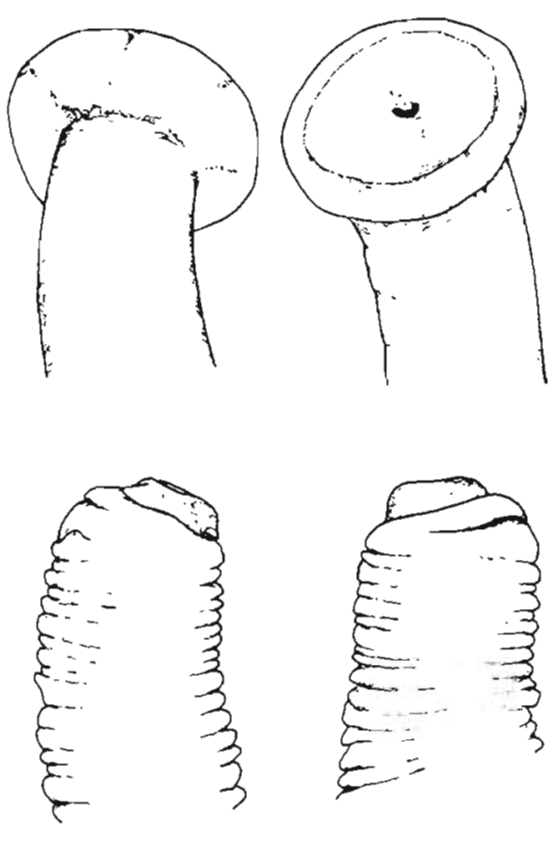

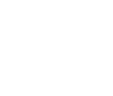

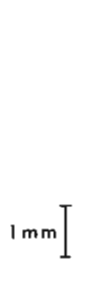

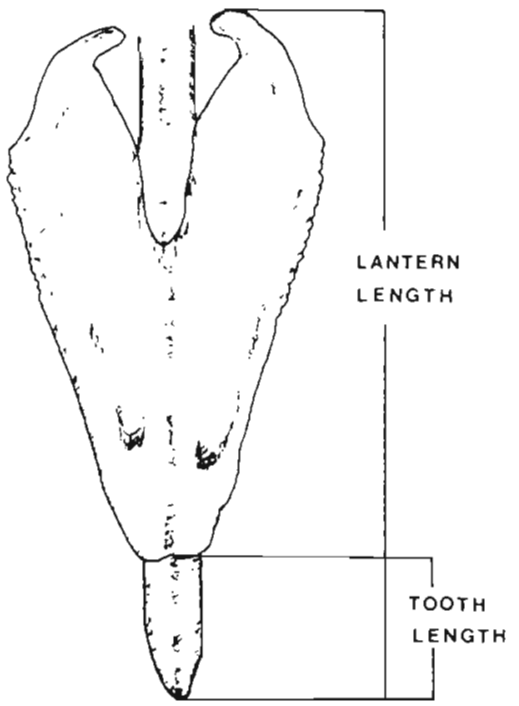




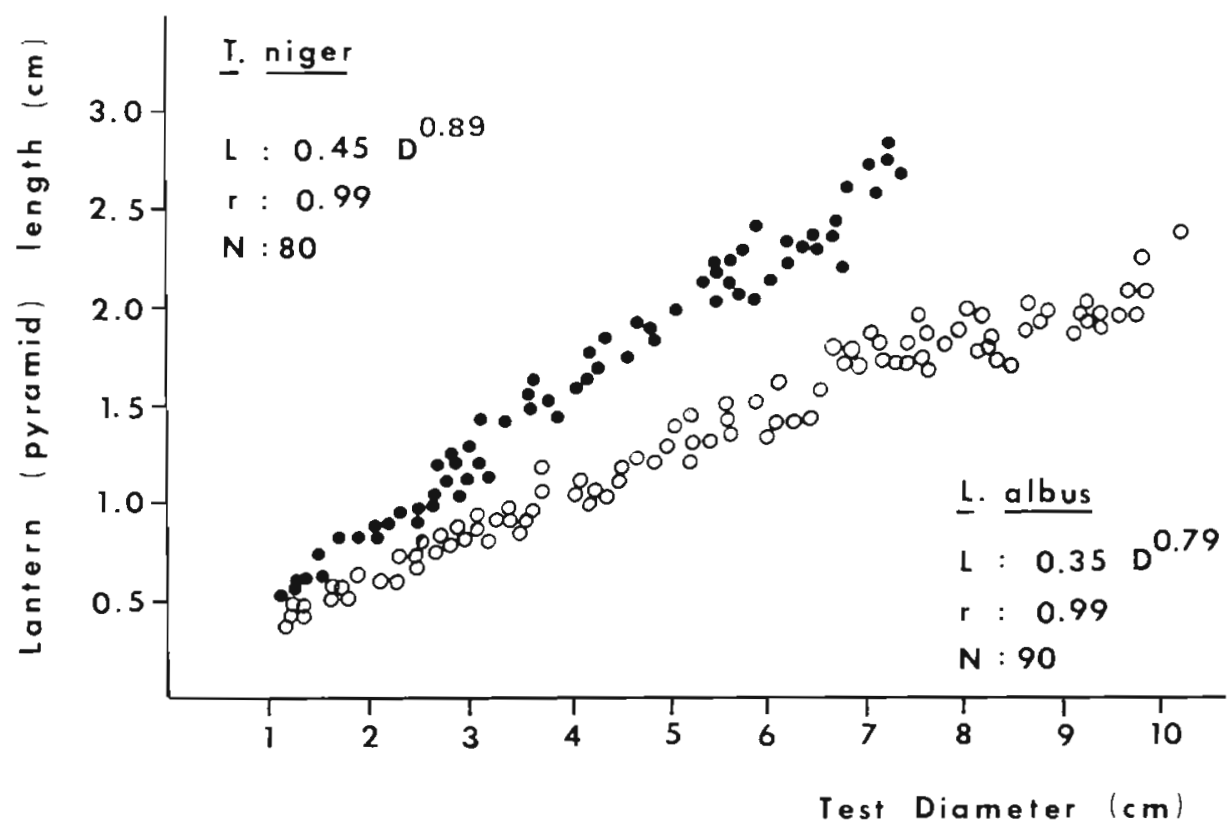

Fig. 5. Loxechinus albus (0) and Tetrapygus niger (•). Lantern length (L) versus test diameter (D)

Aboral podia in $L$. albus are of the $\mathrm{P}_{2}$ type (Smith 1978) ending in a sucker, while those of $T$. niger's are of the $C_{1}$ type (Smith 1978), characteristic of Arbacioids, showing weak sucking discs and simple sensory pads. L. albus has a greater number of podial pairs per ambulacral plate than does $T$. niger (an average of 8 versus 5 pairs of podia). The jaw size of $L$. albus is about half that of $T$. niger in both lantern and tooth length (Fig. 4c).

Fig. 5 shows the relation between lantern length (L) and test diameter (D) for both species. The 2 equations are: Loxecinus albus, $\mathrm{L}=0.35 \mathrm{D}^{0.79}(\mathrm{r}=0.99)$; and Tetrapygus niger, $\mathrm{L}=0.45 \mathrm{D}^{0.89}(\mathrm{r}=0.99)$. The 2 species differ in that the lanterns of $T$. niger are larger than those of $L$. albus for given size individuals. The slopes are significantly different $\left(F_{1,168}=37.45 ; \mathrm{p}<0.001\right)$ and so are the intercepts $\left(F_{1,168}=77.06 ; p<0.001\right)$.

Fig. 6 shows the relation between tooth length (l) and test diameter (D) for both species. The 2 equations are: Loxechinus albus, $\mathrm{l}=0.06 \mathrm{D}^{0.59}(\mathrm{r}=0.82)$ (Fig. 6a); and Tetrapygus niger, $\mathrm{l}=0.10 \mathrm{D}^{0.63}(\mathrm{r}=0.90)$ (Fig. 6b). The 2 species differ in that the teeth of $T$. niger are larger than those of $L$. albus for given size individuals. Indeed, although the slopes are not significantly different $\left(F_{1,168}=0.30 ; p>0.05\right)$, the intercepts are significantly different $\left(F_{1,168}=27.02 ; p<0.001\right)$.

\section{DISCUSSION}

Loxechinus albus and Tetrapygus niger are sympatric sea urchin species found on the rocky shore of central Chile, both in the intertidal and subtidal. Experiments performed in intertidal pools and in the labora- tory revealed that the 2 species have different feeding mechanisms. In field experiments we found that $T$. niger grazes actively on benthic algae and clears more primary space than $L$. albus. Moreover, the grazing of T. niger is intense and generates large halos in the beds of intertidal pool benthic algae. It has been reported that the grazing of $T$. niger on Lessonia nigrescens belts (lower fringe of the rocky intertidal) results in the maintenance and production of primary space (Ojeda \& Santelices 1984). L. albus grazing produces smaller halos. Indeed, Castilla \& Moreno (1982) found that $L$. albus formed small halos on the beds of benthic algae, in Macrocystis pyrifera belts in the subtidal of southernmost Chile. These results contrast with findings by Dayton (1985) who stated that $L$. albus causes and maintains barren grounds in the subtidal zones of southern Chile.

The laboratory experiments disclosed differences between the amounts of algae consumed by Loxechinus albus and Tetrapygus niger (adults and juveniles) in relation to the way in which the algae are offered. At the juvenile stage both sea urchin species consumed more attached algae (i.e. Ulva spp.) or loose algae on the bottom of the tank (i.e. Lessonia nigrescens) than floating algae. This behavioral pattern persists in adult specimens of $T$. niger but not in $L$. albus which feed mostly on drifting algal pieces which they capture with their aboral podia (see Castilla \& Moreno 1982). Differences in feeding behavior between juveniles and adults have also been observed in other seaurchin species, such as Strongylocentrotus droebachiensis: juveniles feed on crustose coralline algae and adults on drifting algae (Lang \& Mann 1976). The feeding rhythms of $L$. albus and $T$. niger are different. 
Fig. 6. (a) Loxechinus albus; (b) Tetrapygus niger. Tooth length (l) versus test diameter (D) of sea urchins

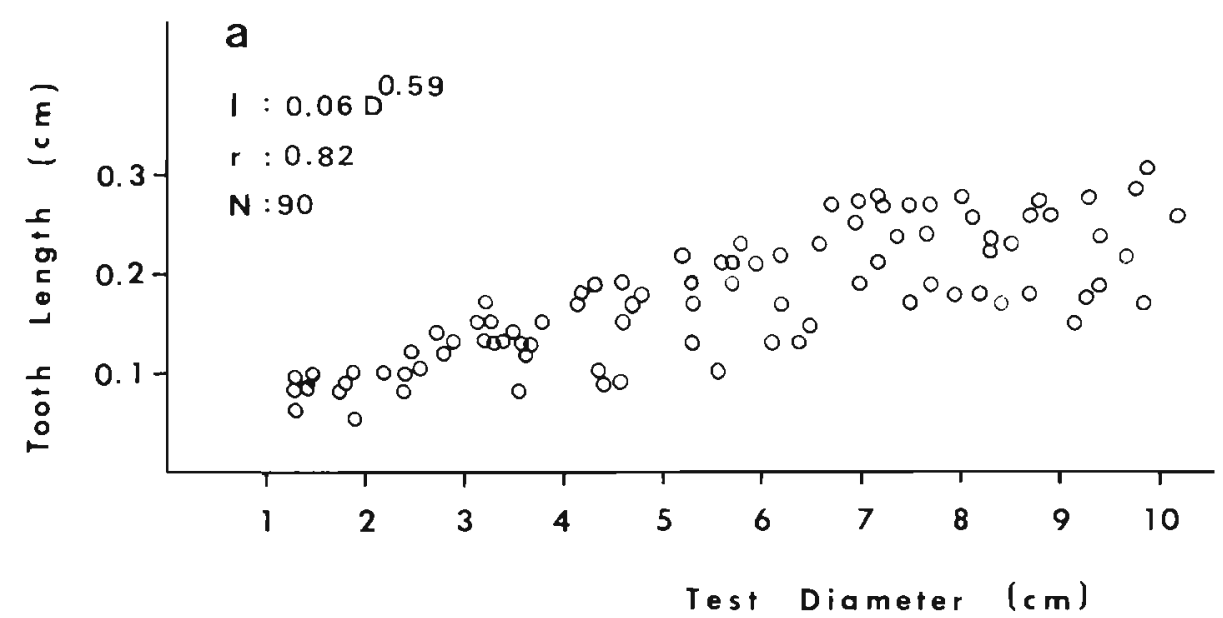

b

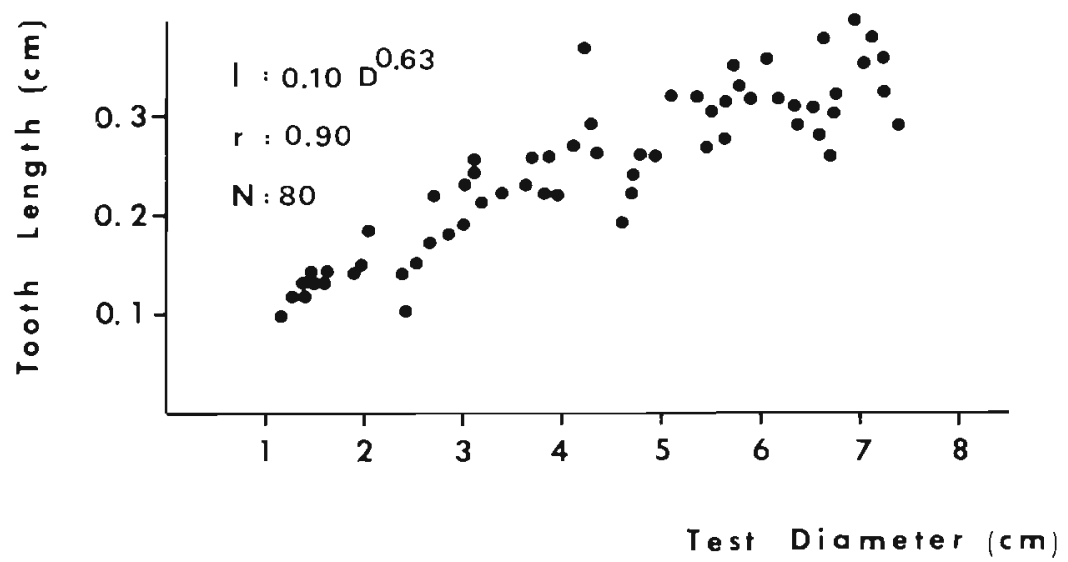

L. albus feeds both during the day and at night, while T. niger feeds mostly at night. Feeding rhythms may be chiefly related to predation (see Lawrence 1975, Nelson \& Vance 1979, Tegner \& Dayton 1981). Our field observations and laboratory experiments indicate that $T$. niger moves mostly at night, and stays in aggregations during daytime. In contrast, no diurnal or nocturnal movements have been observed in $L$. albus. It is worth noting that, unlike $T$. niger, $L$. albus keep their aboral podia in constant motion, and use them for capturing drift algae. Roaf (in Lawrence 1975) has suggested that the modification of podia within the evolutionary development of echinoderns was partly related to feeding processes. These adaptative modifications would involve a tendency toward the lengthening of aboral ambulacral plates, and an increase in size of podia and pores. On the other hand, there is evidence that the size of the terminal sucking disc is directly related to its adhesive power (Sharp \& Gray 1962). All this would contribute to a greater capacity for capturing food. In this context, our results indicate that L. albus has a larger number of podia per ambulacral plate than $T$. niger; also, the aboral podia of $L$. albus have suckers which help in the capture and transport of food to the mouth. The aboral podia of $T$. niger sinow weak sucking discs, and this species obtains food mostly by grazing. Our results also show that the Aristotle's lantern elements (pyramid and tooth) of $T$. niger are bigger than those of $L$. albus. In other sea urchin species (i.e. Echinometra mathei and Strongylocentrotus purpuratus) it has been reported that the size of Aristotle's lantern is related to food availability (Black et al. 1982, Ebert 1982) and starved sea urchins have bigger lanterns than well-fed specimens (Fansler 1983). It has also been found that $E$. mathei individuals with bigger lanterns were able to graze greater areas and contained larger amounts of organic and inorganic matter in their stomachs than those with smaller lanterns (Black et al. 1984). This has been considered an 'adaptive response' (Ebert 1980) and the advantage of a bigger lantern consists in a greater strength for scraping.

The differences found in feeding behavior, morphology of podia, and Aristotle's lantern between adults of Loxechinus albus and Tetrapygus niger indicate that the resources utilized by the 2 species in the intertidal 
differ (benthic versus drift algae) and would be related to adaptive behaviors and morphologies. This does not rule out the possibility of occurrence of plastic responses' (sensu Ebert 1980) in both species. Thus under certain circumstances (i.e. scarcity of drifting algae in the system) the feeding behavior of $L$. albus might be modified from a drifting algae catcher towards a grazer of benthic algae (see contradictory results of Castilla \& Moreno 1982 and of Dayton 1985 for L. albus in southern Chile). The modification of feeding behavior and adaptive morphologies in juveniles and adults of $L$. albus found in this paper seem especially interesting. Indeed it is likely that differentiation in habitats used by each of the population segments (Contreras \& Castilla unpubl.) and their food resources could condition the modifications mentioned above. According to the resuits of the present work, it appears that in central Chile, $T$. niger and $L$. albus only slightly overlap in food type; they would not be competitive regarding this aspect of the niche. Finally their ecological roles in the rocky intertidal are dissimilar, as shown by our field experiments.

Acknowledgements. This study is based on a thesis submitted by the first author as partial fulfillment of the requirements for a Licenciatura degree in Biological Sciences at the Universidad Católica de Chile. We acknowledge financial support from the Dirección de Investigación, Pontificia Universidad Católica de Chile, Research Project 63/84 to J.C.C. The authors are grateful to Jane Lubchenco and Douglas Kelt for suggestions and comments which improved the manuscript. Three anonymous referees made useful suggestions to the final manuscript.

\section{LITERATURE CITED}

Black, R., Codd, C., Hebbert, D., Vink, S., Burt, J. (1984). The functional significance of the relative size of Aristotle's lantern in the sea urchin Echinometra mathei (de Blainville). J. exp. mar. Biol. Ecol. 77: 81-97

Black, R., Johnson, M. S., Trendall, J. T (1982), Relative size of Aristotle's lantern in Echinometra mathei ocurring at different densities. Mar. Biol. 71: 101-106

Castilla, J. C., Cancino, J. (1976). Spawning behaviour and egg capsules of Concholepas concholepas (Mollusca: Gastropoda: Muricidae). Mar. Biol. 37. 255-263

Castilla, J. C., Moreno, C. A. (1982). Sea urchins and Mac- rocystis pyrifera: experimental test of their ecological relations in southern Chile. In: Lawrence, J. M. (ed.) Echinoderms. Proceedings of the International Conference, Tampa Bay, Florida. A. A. Balkema, Rotterdam, p. $257-263$

Dayton, P. K. (1975). Experimental evaluation of ecological dominance in a rocky intertidal algal community. Ecol. Monogr. 45: 137-159

Dayton, P. K. (1985). The structure and regulation of some South American kelp communities. Ecol. Monogr. 55: $447-468$

Ebert, T. A. (1980). Relative growth of sea urchin jaws: an example of plastic resource allocation. Bull. mar. Sci. 30: $467-474$

Ebert, T. A. (1982). Longevity, life history, and relative body wall size in sea urchins. Ecol. Monogr. 52: 353-394

Fansler, S. C. (1983). Phenotypic plasticity of skeletal elements in the purple sea urchin, Strongylocentrotus purpuratus. M.Sc, thesis, San Diego State Univ., San Diego

Lang, C., Mann, K. H. (1976). Changes in sea urchins populations after the destruction of kelp beds. Mar. Biol. 36: $321-326$

Lawrence, J. M. (1975). On the relationships between marine plants and sea urchins. Oceanogr. mar. Biol. A. Rev. 13: 213-286

Leighton, D. L. (1971). Grazing activities of invertebrates in southern California kelp beds. Nova Hedwigia Beihefte 32: $421-453$

Nelson, B. V., Vance, R. R. (1979). Diel foraging patterns of sea urchin Centrostephanus coronatus as a predator avoidance strategy. Mar. Biol. 51: 251-258

Ojeda, F. P., Santelices, B. (1984). Ecological dominance of Lessonia nigrescens (Phaeophyta) in central Chile. Mar. Ecol. Prog. Ser. 19: 83-91

Reese, E. S. (1966). The complex behavior of echinoderms. In: Boolootian, R. A. (ed.) Physiology of Echinodermata. Interscience Publishers, New York, p. 157-218

Sharp, D. T., Gray, I. E. (1962). Studies on factors affecting the local distribution of two sea urchin species, Arbacia punctulata and Lytechinus variegatus. Ecology 43: 309-313

Smith, A. T. (1978). A functional classification of the coronal pores of regular echinoids. Paleontology 21: 759-789

Snedecor, G. W., Cochran, W. G. (1967). Statistical methods, 6 th edn. lowa State Univ. Press, Ames, Iowa

Sokal, R. R., Rohlf, F. J. (1969). Biometry. W. H. Freeman, San Francisco

Tegner, M. J., Dayton, P. K. (1981). Population structure, recruitment and mortality of two sea urchins (Strongylocentrotus franciscanus and $S$. purpuratus) in a kelp forest. Mar. Ecol. Prog. Ser. 5: 255-268

Tegner, M. J., Levin, L. A. (1983). Spiny lobsters and sea urchins: analysis of a predator-prey interaction. J. exp. mar. Biol. Ecol. 73: 125-150 